\title{
OIL-OXIDATION PROPERTIES OF MICROCOCCUS BACTERIA ISOLATED FROM THE NAKHODKA BAY SEAWATER OF THE SEA OF JAPAN
}

(C) 2018

Golozubova Julia Sergeevna, postgraduate student of Ecology Department

Buzoleva Lyubov Stepanovna, doctor of biological sciences, professor, professor of Biodiversity and Marine Bioresources Department

Bogatyrenko Elena Aleksandrovna, candidate of biological sciences, associate professor of Biodiversity and Marine Bioresources Department

Kim Alexandra Vyacheslavovna, postgraduate student of Ecology Department

Eskova Alena Igorevna, postgraduate student of Biodiversity and Marine Bioresources Department Far Eastern Federal University (Vladivostok, Russian Federation)

Abstract. This paper shows the oil-oxidizing ability of Micrococcus bacteria isolated from the Nakhodka Bay surface waters of the Peter the Great Gulf, the Sea of Japan. Micrococcus Bacteria are known to be the most active destructors of petroleum hydrocarbons in natural biotopes, contaminated objects. Voroshilova-Dianova liquid containing 2,5\% oil or oil products was introduced into sterile penicillin bottles with 105 cells of the investigated bacteria. The ability to destruct petroleum hydrocarbons by bacteria of this genus was studied using a gravimetric method during 30 days. Destruction of oil, gasoline, fuel oil and diesel fuel was shown. Micrococcus bacteria showed a high oiloxidizing ability and decompose $65-99,9 \%$ of oil and oil products within 30 days. Gasoline was the source of petroleum hydrocarbons with the greatest ability to utilize this genus of bacteria. The destruction of this hydrocarbons source by bacteria on days 15-20 was about $99 \%$ of the initial concentration. The lowest ability of destruction by Micrococcus bacteria was revealed for diesel fuel.

Keywords: oil-oxidizing bacteria; Micrococcus sp.; fuel oil; petrol; oil; diesel fuel; Nakhodka bay; anthropogenic pollution; marine microorganisms; ecological monitoring; the Sea of Japan; the Gulf of Peter the Great; gravimetric method; destruction of petroleum hydrocarbons.

УДК 581.55

Статья поступила в редакцию 16.04 .2018

\section{ШИРОКОЛИСТВЕННЫЕ НАСАЖДЕНИЯ \\ РАЙОНА ШИРОКОЛИСТВЕННО-ТЕМНОХВОЙНЫХ ЛЕСОВ ЮЖНОГО УРАЛА (НЕКОТОРЫЕ РЕЗУЛЬТАТЫ ИССЛЕДОВАНИЙ)}

(C) 2018

Горичев Юрий Петрович, кандидат биологических наук, заместитель директора по научной работе

Юсупов Ильдар Равилевич, кандидат биологических наук, старший научный сотрудник

Южно-Уральский государственный природный заповедник

(n. Реветь, Белорецкий район, республика Башкортостан, Российская Федерация)

Давыдычев Александр Николаевич, кандидат биологических наук,

старший научный сотрудник лаборатории лесоведения

Кулагин Алексей Юрьевич, доктор биологических наук, профессор, заведующий лабораторией лесоведения

Уфимский институт биологии РАН (2. Уфа, Российская Федерация)

Аннотация. В статье представлены результаты исследований широколиственных насаждений в районе широколиственно-темнохвойных лесов Южного Урала. Стационарные исследования проведены на территории Южно-Уральского государственного природного заповедника, где были заложены 9 пробных лесных площадей в разных типах широколиственных насаждений. На пробных площадях проведены исследования стандартными методами, заложены почвенные разрезы, проведены микроклиматические наблюдения с использованием цифровых термометров-регистраторов «Термохрон». В результате исследований получены данные о структуре и строении характерных типов широколиственных насаждений с преобладанием дуба и клёна. Проведена классификация биогеоценозов (типов леса) и фитоценозов (типов насаждений), выделены 3 типа леса и 4 типа насаждений. Исследованные насаждения с преобладанием дуба отнесены к 2 типам коренных насаждений: дубняк снытево-разнотравный и дубняк сыртовый или остепненный, насаждения с преобладанием клёна также отнесены к 2 типам коренных насаждений: кленовник снытево-разнотравный и кленовник высокотравный. Исследованиями установлена приуроченность типов широколиственных насаждений к определенным элементам рельефа и высотным уровням. Экотопический ареал широколиственных насаждений предельно сужен, вследствие чего их фитоценотический спектр сильно обеднен. Полученные материалы представляют основу для дальнейшего мониторинга лесов.

Ключевые слова: Южный Урал; район широколиственно-темнохвойных лесов; широколиственные насаждения; тип леса; тип насаждения; дубняк; кленовник; экотоп; экотопический ареал; пробная площадь; древостой; класс бонитета; запас древесины; плотность подроста; эколого-ценотическая группа; Южно-Уральский заповедник.

\section{Введение}

Район широколиственно-темнохвойных лесов охватывает низкогорья западного склона Южного Ура- ла к северу от 54 параллели, находящиеся в пределах Республики Башкортостан и Челябинской области. Горные широколиственные леса Южного Урала, 
Горичев Ю.П., Юсупов И.Р., Давыдычев А.Н., Кулагин А.Ю.

преимущественно района широколиственных лесов, исследованы П.Л. Горчаковским [1; 2] и С.Ф. Курнаевым [3]. Ими выполнены описания характерных ассоциаций, предложена их классификация. Ряд исследований проведен на границе района [4-6]. Неизученными остаются широколиственные леса района широколиственно-темнохвойных лесов. Это предопределяет актуальность их исследования с целью сохранения и рационального лесопользования.

\section{Цель и объекты исследования}

Исследования проведены в 2004-2016 гг. Цель исследования - выявление особенностей структуры и строения широколиственных насаждений, закономерности их пространственной дифференциации. Маршрутными исследованиями охвачена юго-западная часть района широколиственно-темнохвойных лесов Южного Урала. Стационарные исследования проведены на территории Южно-Уральского государственного природного заповедника. Для изучения структуры и строения широколиственных насаждений заложены 9 пробных площадей (ПП), в том числе 5 ПП - в насаждениях с преобладанием дуба, 4 ПП - с преобладанием клёна. 8 ПП размером $50 \times 50$ м, одна площадь (ПП-39) - размером $25 \times 25 \mathrm{M}$.

\section{Материалы и методика исследований}

На пробных площадях проведены исследования строения древостоя, учет возобновления с использованием стандартных методов, принятых в лесоведении [7-9], с некоторыми модификациями [10]. Выполнены геоботанические описания, проанализирована эколого-ценотическая структура травянистого яруса в соответствии с рекомендациями О.В. Смирновой и др. [11]. На ПП изучены морфологические свойства почв посредством закладки почвенных разрезов по общепринятой методике [12], проведены микроклиматические наблюдения с использованием термодатчиков «Термохрон». Описания и подробные таксационные характеристики насаждений, описания почвенных разрезов, представлены нами в ряде публикаций [13-17].

\section{Результаты исследований и их обсуждение}

В районе широколиственно-темнохвойных лесов в состав древостоя широколиственных насаждений входят 4 вида широколиственных деревьев - дуб черешчатый (Quercus robur L.), клён остролистный (Acer platanoides L.), липа сердцелистная (Tilia cordata Mill.), ильм горный (Ulmus glabra Huds.). Также в составе древостоя в том или ином количестве присутствуют мелколиственные виды деревьев - береза повислая (Betula pendula Roth.) и осина (Populus tremula L.). В некоторых насаждениях в состав древостоя входят единичные деревья пихты сибирской (Abies sibirica Ledeb.). Общими чертами структуры нижних ярусов насаждений является разреженный кустарниковый ярус, образованный черемухой (Padus avium Mill.), лесными кустарниками и полукустарниками (Sorbus aucuparia L., Lonicera xylosteum L., Rubus idaeus L., Rosa majalis Herm.). Травянистый ярус хорошо развит, характеризуется значительным видовым богатством. В эколого-ценотическом спектре доминируют неморальные виды, с той или иной долей присутствуют представители других групп высокотравные, лугово-опушечные и нитрофильные виды. Моховой ярус не выражен, мхи отдельными пятнами покрывают камни и валежники.

В соответствии с критериями, принятыми в лесной типологии [18; 19], в районе исследований нами выделены 3 типа леса: широколиственные леса на выпуклых вершинах и узких гребнях увалов (сокращенно ксерофильные широколиственные леса увалов) со свежими, периодически сухими почвами; широколиственные леса на пологих участках верхних частей склонов увалов и невысоких гор (мезофильные широколиственные леса увалов) со свежими, периодически влажными почвами; широколиственные леса на пологих и вогнутых участках средних частей склонов высоких хребтов (мезофильные широколиственные леса высоких хребтов) с устойчиво влажными почвами [17]. Выделенные типы леса различаются условиями увлажнения, мощностью почвенных горизонтов, а также параметрами теплообеспеченности. В первых двух типах леса в составе древостоя коренных насаждениях преобладают дуб или клён, в третьем типе леса доминирует преимущественно клен. Ниже приводится характеристика типов насаждений. Таксационные характеристики древостоев представлены в таблице 1, показатели возобновления - в таблице 2 .

Таблица 1 - Основные таксационные характеристики древостоев (по [17, с. 186-187, табл. 1])

\begin{tabular}{|c|c|c|c|c|c|c|}
\hline $\begin{array}{c}\text { Тип } \\
\text { насаждения }\end{array}$ & $\begin{array}{c}\text { Состав } \\
\text { древостоя }\end{array}$ & $\begin{array}{c}\text { №№ } \\
\text { ПП }\end{array}$ & $\begin{array}{c}\text { Класс } \\
\text { бонитета }\end{array}$ & $\begin{array}{l}\text { Пол- } \\
\text { нота }\end{array}$ & $\begin{array}{c}\text { Плотность дре- } \\
\text { востоя, шт./га }\end{array}$ & $\begin{array}{l}\text { Запас древе- } \\
\text { сины, } \text { м }^{3} \text { га }\end{array}$ \\
\hline \multicolumn{7}{|c|}{ Насаждения с преобладанием дуба } \\
\hline \multirow{4}{*}{$\begin{array}{l}\text { Дубняк } \\
\text { снытево- } \\
\text { разнотравный }\end{array}$} & 7Д1Лп1Б1Кл+Ил, ед.Ос & 38 & II & 1,2 & 636 & 426,6 \\
\hline & 5Д2 Кл1Б 1Лп1Ос, ед.Ил & 40 & I & 0,9 & 808 & 411,5 \\
\hline & \begin{tabular}{|l} 
5Д2Лп1 Кл 1Ил1П \\
\end{tabular} & 47 & II & 0,8 & 776 & 375,3 \\
\hline & 5Д2Кл2Лп1Ил, ед.П & 48 & II & 0,8 & 368 & 290,4 \\
\hline $\begin{array}{l}\text { Дубняк } \\
\text { остепненный }\end{array}$ & 7Д1Кл2Лп & 39 & $\mathrm{~V}$ & 0,8 & 712 & 186,0 \\
\hline \multicolumn{7}{|c|}{ Насаждения с преобладанием клена } \\
\hline \multirow{3}{*}{$\begin{array}{l}\text { Кленовник } \\
\text { снытево- } \\
\text { разнотравный }\end{array}$} & 5Кл2Лп2Ил1Д+П & 41 & $\mathrm{I}$ & 0,9 & 608 & 198,5 \\
\hline & 4Кл3Д2П1Лп, ед. Ил, Б & 49 & II & 0,8 & 772 & 376,5 \\
\hline & 8Кл1Б1Ил+Лп, ед.Ос, П & 51 & III & 0,8 & 468 & 302,2 \\
\hline $\begin{array}{l}\text { Кленовник } \\
\text { высокотравный }\end{array}$ & 5Кл4Лп1П+Ил & 35 & III & 1,4 & 600 & 351,2 \\
\hline
\end{tabular}


Горичев Ю.П., Юсупов И.Р., Давыдычев А.Н., Кулагин А.Ю.

Широколиственные насаждения района широколиственно-темнохвойных лесов..

03.02.00 - общая биология

Таблица 2 - Плотность подроста, тыс. шт./га (по [17, с. 187, табл. 2])

\begin{tabular}{|c|c|c|c|c|c|c|c|c|}
\hline \multirow{2}{*}{ Тип насаждения } & \multirow{2}{*}{$\begin{array}{c}\text { №№ } \\
\text { ПП }\end{array}$} & \multicolumn{6}{|c|}{ Породы } & \multirow{2}{*}{ Всего } \\
\hline & & Дуб & Клён & Липа & Ильм & Пихта & Осина & \\
\hline \multirow{4}{*}{$\begin{array}{l}\text { Дубняк } \\
\text { снытево- } \\
\text { разнотравный }\end{array}$} & 38 & $20,4 / 0,0$ & $37,2 / 2,2$ & $0,8 / 0,2$ & $9,6 / 3,2$ & - & $0,0 / 0,1$ & $68,0 / 5,7$ \\
\hline & 40 & $20,0 / 0,0$ & $11,6 / 0,1$ & $0,8 / 4,2$ & $0,0 / 0,5$ & - & $0,4 / 0,0$ & $32,8 / 4,8$ \\
\hline & 47 & $3,0 / 0,0$ & $13,0 / 0,0$ & $0,0 / 0,7$ & $3,2 / 1,0$ & $0,2 / 0,7$ & - & $19,4 / 2,4$ \\
\hline & 48 & $2,4 / 0,5$ & $15,0 / 0,4$ & - & $6,0 / 1,7$ & - & - & $23,4 / 2,6$ \\
\hline Дубняк остепненный & 39 & $0,4 / 0,3$ & $4,4 / 0,2$ & $0,0 / 0,5$ & $0,0 / 0,2$ & - & - & $4,8 / 1,2$ \\
\hline \multirow{3}{*}{$\begin{array}{l}\text { Кленовник } \\
\text { снытево- } \\
\text { разнотравный }\end{array}$} & 41 & $0,0 / 0,1$ & $9,2 / 0,4$ & $0,0 / 0,2$ & $4,8 / 4,2$ & $0,0 / 0,1$ & - & $14,0 / 4,9$ \\
\hline & 49 & $0,6 / 0,0$ & $17,8 / 0,0$ & $0,4 / 0,4$ & $1,0 / 1,3$ & $0,0 / 0,2$ & - & $19,8 / 1,9$ \\
\hline & 51 & - & $17,2 / 0,3$ & - & $0,4 / 4,3$ & - & - & $17,6 / 4,7$ \\
\hline Кленовник высокотравный & 35 & - & $2,8 / 0,2$ & $0,0 / 2,4$ & $32,4 / 0,9$ & $0,0 / 0,1$ & - & $37,6 / 1,2$ \\
\hline
\end{tabular}

Примечание. В числителе указана плотность мелкого подроста, в знаменателе - крупного.

Насаждения с преобладанием дуба. По классификации П.Л. Горчаковского [2] исследованные дубовые насаждения относятся к классу прямоствольных дубняков. Согласно классификации Г.В. Попова [20], они представляют группы ксерофильных и мезофильных типов насаждений. Исследованные насаждения с преобладанием дуба отнесены нами к 2 типам насаждений: дубняк снытево-разнотравный и дубняк остепненный, представляющие 2 разных типа леса [17].

Дубняк снытево-разнотравный. Отнесен нами к типу леса мезофильные широколиственные леса увалов [17]. Данный тип насаждений аналогичен ассоциации дубняк разнотравно-снытевый, описанной П.Л. Горчаковским [2, с. 28] в районе широколиственных лесов. Он характеризуется высокими показателями бонитета (I-II), полноты древостоя и запаса древесины. Участие дуба в составе древостоя составляет 5-7 единиц, клёна и липы - 1-2 единицы, ильма - не более 1 единицы. В возобновлении участвуют все широколиственные породы. Возобновление липы вегетативное, остальных пород - семенное. Подрост дуба редкий, преимущественно мелкий (высотой менее 50 см), крупный подрост единичный, часто отсутствует. Подрост клёна более многочислен, чем подрост дуба. Возобновление липы и ильма слабое, их подрост преимущественно крупный, мелкий подрост часто отсутствует. Иногда встречается единичный подрост пихты. В составе разреженного подлеска черемуха и лесные кустарники. В травянистом ярусе господствуют неморальные виды, доминируют Aegopodium podagraria L., Carex pilosa Scop., Stellaria holostea L., Carex digitata L., высокое обилие имеют Galium odoratum L., Pulmonaria obscura Dumort., Asarum europaeum L., Stachys sylvatica L., Dryopteris filix-mas L., Geum urbanum L., Calamagrostis arundinacea Roth, Brachypodium pinnatum L., обычны виды высокотравья (Aconitum septentrionale Rchb., Crepis sibirica L., Heracleum sibiricum L., Cicerbita uralensis Beauverd, Cacalia hastate L.,) и некоторые луговоопушечные виды (Stachys officinalis L.).

Дубняк остепненный сыртовый. Отнесен нами к типу леса ксерофильные широколиственные леса увалов [17]. Данный тип насаждений аналогичен ассоциации дубняк коротконожково-снытево-тростниковидновейниковый, описанной П.Л. Горчаковским [2, с. 44]. Характеризуется одноярусным ярусом древостоя, низкими показателями бонитета $(\mathrm{V})$ и запаса древесины. Древостой образует дуб с участием клёна и липы. В редком подросте представлены все широколиственные породы. Подрост клёна более многочислен, чем дуба, он в основном мелкий, также встречается крупный подрост липы и ильма. Разреженный подлесок образуют лесные кустарники с участием Rosa glabrifolia L. и Cotoneaster melanocarpus Fisch. ex Blytt. В травянистом ярусе широко представлены лугово-лесные и лесостепные виды (Phlomis tuberose L., Digitalis grandiflora Mill., Dracocephalum ruyschiana L., Aconitum anthora L., Verbascum nigrum L., Achillea milefolium L.), в числе доминантов Carex digitata L., Carex pilosa Scop., Poa protensis L., Calamagrostis arundinacea Roth, обильны Thalictrum minus L., Trifolium medium L., Galium boreale $\mathrm{L}$.

Насаждения с преобладанием клёна. Кленовые насаждения более широко распространены и занимают большую площадь лесного фонда, чем дубовые. Исследованные насаждения отнесены нами к 2 типам коренных насаждений: кленовник снытеворазнотравный и кленовник высокотравный, представляющие 2 разных типов леса [17]. В кленовых насаждениях часто встречаются единичные деревья и подрост пихты.

Кленовник снытево-разнотравный. Отнесен нами к типу леса мезофильные широколиственные леса увалов [17]. Данный тип насаждений по ряду признаков сравним с ассоциацией кленовник ясменниково-снытевый, описанной П.Л. Горчаковским [2, c. 102]. Таксационные показатели исследованных насаждений сильно варьируют в зависимости от класса возраста насаждений. В составе древостоя доминирует клён, присутствуют (1-2 единицы) дуб, липа и ильм. В возобновлении участвуют все широколиственные породы. Подрост клёна преимущественно мелкий, подрост дуба единичный или отсутствует, подрост липы редкий, преимущественно крупный, обычен подрост ильма. Редкий подлесок формируют черемуха и лесные кустарники. В травянистом ярусе доминируют Stellaria holostea L., Dryopteris filix-mas L., Carex pilosa Scop., Carex digitata L., Aegopodium podagraria L., Galium odoratum L., встречается ряд видов высокотравья.

Кленовник высокотравный. Отнесен нами к типу леса мезофильные широколиственные леса высоких хребтов [17]. Данный тип насаждений аналогичен ассоциации кленовник крупнопапоротниковый, описанной П.Л. Горчаковским [2, с. 96]. Характеризуется средними показателями бонитета (III), полноты древостоя и запаса древесины. В составе древостоя часто отсутствует дуб, преобладающая порода клён, значительно участие липы (до 4 единиц), единичны ильм и пихта. В подросте представлены все широколиственные породы, за исключением дуба. Подрост клёна и липы редкий, подрост липы пре- 
Горичев Ю.П., Юсупов И.Р., Давыдычев А.Н., Кулагин А.Ю.

имущественно крупный, многочислен мелкий подрост ильма, встречается единичный крупный подрост пихты. В редком подлеске рябина, черемуха и малина. В травянистом ярусе домируют Aegopodium podagraria L., Galium odoratum L., Pulmonaria obscura L., Dryopteris filix-mas L., Carex pilosa Scop., Stellaria holostea L., присутствует значительное число видов из группы высокотравья (Aconitum septentrionale Rchb., Heracleum sibiricum L., Crepis sibirica L., Valeriana officinalis L., Cacalia hastate L., Campanula latifolia L.), встречается ряд нитрофильных и бореальных видов.

\section{Bыводы}

В районе широколиственно-темнохвойных лесов широколиственные насаждения занимают небольшие площади. Экотопический ареал широколиственных лесов в данном районе предельно узкий. Их распространение связано с наиболее теплыми местообитаниями. Фитоценотический спектр широколиственных насаждений весьма беден. Выделены 4 типа коренных широколиственных насаждений с преобладанием дуба и клёна, которые отнесены к 3 типам леса.

\section{Список литературы:}

1. Горчаковский П.Л. Растения европейских широколиственных лесов на восточном пределе их ареала. Свердловск: Уральск. филиал АН СССР, 1968. $206 \mathrm{c}$.

2. Горчаковский П.Л.Широколиственные леса и их место в растительном покрове Южного Урала. М.: Наука, 1972. 146 с.

3. Курнаев С.Ф. Теневые широколиственные леса Русской равнины и Урала. М.: Наука, 1980. 316 с.

4. Петров Г.П. Ашинские дубравы // Памятники природы. Охрана природы на Урале. Свердловск, 1967. Вып. 6. С. 89-98.

5. Кожевников А.П., Годовалов Г.А., Гнеушева Т.М. Закономерности распространения дуба черешчатого в лесных экосистемах Челябинской области // Известия Оренбургского государственного аграрного университета. 2011. № 4 (32). С. 18-21.

6. Кожевников А.П., Годовалов Г.А., Гнеушева Т.М. Инвентаризация монодоминантных позднесуцессионных фитоценозов с дубом черешчатым на экотоне темнохвойно-широколиственных и бореальных лесов // Леса России и хозяйство в них. Вып. 3 (40). Екатеринбург, 2011. С. 45-50.

7. Сукачев В.Н., Зонн С.В. Методические указания к изучению типов леса. М.: Изд-во АН СССР, 1961. 144 c.

\section{BROAD-LEAVED PLANTS OF THE SOUTHERN URALS BROAD-LEAVED-CONIFER FORESTS (SOME RESULTS OF THE STUDIES)}

(C) 2018

Gorichev Yuriy Petrovich, candidate of biological sciences, deputy director for science

Yusupov Ildar Ravilevich, candidate of biological sciences, senior researcher

South Ural State Nature Reserve (Revet, Beloretsky District, Republic of Bashkortostan, Russian Federation)

Davydychev Alexander Nikolaevich, candidate of biological sciences, senior researcher of Forest Science Laboratory

Kulagin Aleksey Yurievich, doctor of biological sciences, professor, head of Forest Science Laboratory Ufa Institute of Biology of Russian Academy of Sciences (Ufa, Russian Federation)

Abstract. The paper deals with the study of broad-leaved plants of the Southern Urals broad-leaved-conifer forests. Stationary studies were conducted on the territory of the South Ural state natural reserve, where 9 forest sites in 
different types of broad-leaved forests were laid. The research used standard methods while microclimatic observations used digital thermometers-recorders «Thermochron». The authors have obtained some data on the structure and composition of the characteristic types of broad-leaved forests with oak and maple domination. The authors have classified ecosystems and plant communities, selected 3 types of biogeocenoses and 4 types of phytocoenoses. Studies have established that selected types of broad-leaved forests are associated to certain elements of relief and highaltitude levels. The obtained materials provide the basis for further monitoring of forests.

Keywords: Southern Urals; broad-leaved-dark coniferous forests; deciduous forests; ecosystem type; type of phytocenosis; oak wood; maple wood; ecotope; ecotopic habitat; registration area; wood layer; growth class; timber reserves; density of undergrowth; ecological-coenotic group; South Ural reserve.

УДК 582.734.3+534.1

Статья поступила в редакцию 07.04.2018

\title{
К ОСОБЕННОСТЯМ МИРОВОГО И РОССИЙСКОГО ПРОИЗВОДСТВА ПЛОДОВОЙ ПРОДУКЦИИ (ЯБЛОК И гРУШ)
}

(C) 2018

\author{
Деменина Любовь Георгиевна, заместитель директора по науке \\ Научно-исследовательский институт садоводства и лекарственных растений «Жигулёвские сады» \\ (2. Самара, Российская Федерация) \\ Петрова Анна Борисовна, аспирант кафедры экологии, ботаники и охраны природы \\ Савицкая Кристина Андреевна, аспирант кафедры экологии, ботаники и охраны природы \\ Кавеленова Людмила Михайловна, доктор биологических наук, профессор, \\ заведующий кафедрой экологии, ботаники и охраны природы \\ Самарский национальный исследовательский университет имени академика С.П. Королёва \\ (2. Самара, Российская Федерачия)
}

\begin{abstract}
Аннотащия. В статье рассматриваются биологические особенности важнейших плодовых культур умеренных широт, принадлежащих к семейству Rosaceae, подсемейству Maloideae - яблони и груши, с учетом специфики их мирового, национального и регионального возделывания. Обе культуры характеризуются значительным пищевым и товарным значением, имеют некоторые различия в химическом составе плодов, включая ведущие компоненты массы и биологически активные вещества, что определяет особенности их использования в рационе человека. Как в мировом, так и в национальном плодоводстве груша по сравнению с яблоней играет второстепенную роль, уступая ей по числу сортов, объему продукции и занятым площадям. На основе анализа доступных статистических данных базы ФАО рассматривается динамика изменения с 1990 по 2016 гг. мирового производства плодов яблони и груши с визуализацией по континентам, выявлением мировых лидеров и основных тенденций. Для СССР (с 1962 по 1990 гг.) и в дальнейшем - РФ (с 1992 по 2016 гг.) также представлена картина изменения объема данной плодовой продукции, обсуждается вопрос о состоянии обеспечения плодовой продукцией населения страны. Обсуждаются особенности исторического развития и современного состояния плодоводства в Самарской области и перспективы его дальнейшего развития.

Ключевые слова: семейство розоцветные; плодовые культуры умеренных широт; представители подсемейства Maloideae; яблоня; груша; разнообразие сортов; выращивание в странах мира; динамика изменений; производство плодов по континентам; особенности производства плодовой продукции в РФ; перспективы промышленного садоводства в Самарской области.
\end{abstract}

\section{Введение}

Семейство розоцветные (Rosaceae) - распространенная в умеренных широтах группа цветковых растений, включающая около 3 тыс. видов, принадлежащих к 100 родам [1]. Само семейство имеет различные жизненные формы, такие как травы, кустарники, а также лианы. Листья обычно чередуются от простых до пальчато- или перисто-сложных. Прилистники чаще всего присутствуют, цветки яркие, обоеполые или редко однополые. Плоды могут быть различными (орешек, костянка, яблоко, семянка, листовка, коробочка). Эндосперм присутствует в семенах. Если говорить об экономической значимости, розоцветные включают в себя значительное число видов, в частности, плодовых культур умеренных широт. Только в 2005 г. общее мировое производство съедобных плодов розоцветных, согласно статистическим данным ФАО, составило около 113 млн тонн. Данное семейство имеет широкий ареал распространения, но большее разнообразие видов находится в Северном полушарии. Травянистые виды произрастают в умеренных лесах как подлески растений, в соленых или пресноводных болотах в тундре, даже порой на обочинах дорог. Древесные формы также иногда встречаются в смешанных лиственных лесах [2].

Подсемейство Maloideae, входящее в состав семейства розоцветных, включает в себя важные съедобные виды умеренных широт, которые в соответствии с типом плода (яблоко, яблочко) именуют семечковыми. Они широко востребованы в плодоводстве и ландшафтном дизайне. Наиболее экономически значимыми видами розоцветных являются яблоня и груша, имеющие крупные съедобные плоды, существует и целый ряд мелкоплодных представителей подсемейства, имеющих хозяйственную значимость.

Вид Malus $\times$ domestica $=$ M. pumila является наиболее экономически важным видом розоцветных с показателем ежегодного мирового производства плодов (2005) свыше 62 млн тонн и занимает четвертое место среди плодовых после цитрусовых, винограда и банана. Яблоки производятся во всех уме- 